\title{
Celecoxib Decreases Mitochondrial Complex IV Activity and Induces Oxidative Stress in Isolated Rat Heart Mitochondria: An Analysis for its Cardiotoxic Adverse Effect
}

\section{Saman Atashbar}

Ardebil University of Medical Sciences

Elham Mohammad Khanlou

Ardebil University of Medical Sciences

\section{Saleh Khezri}

Ardebil University of Medical Sciences

\section{Peyman Kurdpour}

Ardebil University of Medical Sciences

Ahmad Salimi ( $\sim$ salimikd@yahoo.com )

Ardebil University of Medical Sciences https://orcid.org/0000-0003-3026-6398

\section{Research article}

Keywords: Celecoxib, Mitochondria, Cardiotoxicity, Mitochondrial Complexes, Heart

Posted Date: November 24th, 2020

DOI: https://doi.org/10.21203/rs.3.rs-61517/v1

License: (c) (1) This work is licensed under a Creative Commons Attribution 4.0 International License. Read Full License

Version of Record: A version of this preprint was published at Journal of Biochemical and Molecular Toxicology on October 19th, 2021. See the published version at https://doi.org/10.1002/jbt.22934. 


\section{Abstract \\ Background}

In spite of the cardiotoxic effect of selective cyclooxygenase- 2 inhibitors, they are most widely used as anti-inflammatory and analgesic drugs. Today, valdecoxib and rofecoxib have been withdrawn on the market but celecoxib remains. In this study, we focused on an analysis of celecoxib toxic effects on isolated mitochondrial.

\section{Methods}

isolated rat heart mitochondria were obtained using differential centrifugation. Using flowcytometry and biochemical assays we searched succinate dehydrogenases (SDH), mitochondrial membrane potential (MMP), reactive oxygen species (ROS) formation, mitochondrial swelling, lipid peroxidation and mitochondrial complexes activity in rat heart isolated mitochondria.

\section{Results}

In here our results indicated a significant decrease in activity of complexes IV after exposure with celecoxib $(16 \mu \mathrm{g} / \mathrm{ml})$. This decrease in activity of complexes IV is paralleled by the MMP collapse, ROS formation, mitochondrial swelling and lipid peroxidation.

\section{Conclusion}

For the first time, this introductory study has showed a significant decrease in activity of complexes IV and mitochondrial dysfunction after exposure with celecoxib in rat heart isolated mitochondria.

\section{Background}

For the management of various inflammatory conditions and short and long-term pain, nonsteroidal antiinflammatory drugs (NSAIDs) are most widely used in the clinic (1). The long usage of this drug class is associated with wide array of side effects including stomach pain, stomach ulcers, a tendency to bleed more, headaches and dizziness, ringing in the ears, allergic reactions, liver or kidney problems, high blood pressure and increased risk of cardiovascular complications (2). NSAIDs inhibit the cyclooxygenase (COX) enzymes and in this way, have an important role in the pain relieving in the various inflammatory conditions (3). Also, COX enzymes play a key role in conversion of arachidonic acid into prostaglandins (PGs) and thromboxanes (TXs) (4). The coxibs such as rofecoxib, valdecoxib and celecoxib are potent COX-2 inhibitors that are categorized under the class of NSAIDs (5). Disbalance between the prostacyclin (PGI2) and thromboxane A2 (TXA2) amounts is due to coxibs responsible for the cardiovascular abnormality such as atherosclerosis, thrombosis, and etc.(6). It has been reported that use of celecoxib is 
associated with increased risk of myocardial infarction (7). Previous studies have been reported that long term use of celecoxib is associated with risk factor for the cardiovascular complications such as myocardial infarction, stroke, and heart failure (8). Ahmad et al. in an animal study reported that celecoxib produced cardiotoxicity in rats as evident by the release of myocyte injury markers into serum $(9,10)$. The exact mechanism by which celecoxib might prompt cardiotoxicity is not clearly identified therefor further investigations are needed.

Multiple lines of evidence strongly suggest that the cardiotoxicity of NSAIDs direct or indirect are associated with mitochondria, which is comprised of inhibition of the important mitochondrial enzymes, interference with the mitochondrial respiratory chain and inhibition of the mitochondrial DNA replication which eventually leading to an increase in mitochondrial oxidative stress, loss of mitochondrial membrane potential and cell death (11-13). Mitochondria play a critical role in supplying ATP (adenosine triphosphate) for the cells. Therefore, the cells and tissues with a high aerobic energy requirement is more sensitive to mitochondrial toxic agents (14). Also, the very important enzymes such as heme synthesis, fatty acid urea synthesis and $\beta$-oxidation reside within the mitochondrial matrix (14). As a result, tissues like cardiac tissues that rely heavily on these processes are almost targets of mitochondrial toxins. Cardiomyocytes contain a large number of mitochondria, when enough mitochondria are irreparably damaged and the cell cannot provide its energy requirements, in this condition cellular injury or dysfunction will occur $(15,16)$. These unique functions of mitochondria in cardiomyocytes stimulate researchers to pay more attention to the interrelationships between drugs and mitochondria for both the toxic and therapeutic aspects. Also, a published work indicated that the predictive performance of the mitochondrial assays for evolution of cardiotoxicity is $33 \%$ (17).

In spite of significant efforts for identification drug-related cardiotoxicity in preclinical assessments, safety concerns still remain. This is most likely due to the lack of sufficient understanding of the molecular pathways leading to cardiotoxicity (18). The exact mechanism by which celecoxib induce cardiotoxicity is not known. Mitochondria have an essential role in myocardial tissue homeostasis; thus, deterioration in mitochondrial function could result in cardiomyocyte and endothelial cell death and consequently cardiovascular dysfunction. To our knowledge, there are no reports to date about the effect of celecoxib on heart isolated mitochondria and mitochondrial complexes. Thus, the present study aims to study the effect of celecoxib on mitochondrial complexes and toxicity parameters.

\section{Methods}

\section{Animals}

A total of 30 male wistar rats weighing 200-300 g was obtained from the Pasteur Institute of Iran (Tehran, Iran). The rats were placed in the animal house facility of the School of Pharmacy of the Ardabil University of Medical Sciences. The rats were housed in a 12-h dark/light cycle with an air-conditioned room and temperatures $25 \pm 2 \mathrm{C}^{\circ}$. The rats were fed with standard rat chow ad libitum and water. Animals were acclimated in the animal house prior the experiments for 2 weeks. The study was performed 
according to the institutional and international guidelines for the Care and Use of Laboratory Animals. All protocols were approved by the Ethics Committee at the Ardabil University of Medical Sciences.

\section{Chemicals}

Cytochrome c (Cyt c), 2,6-dichlorophenolindophenol (DCPIP), decylubiquinone (DUB), decylubiquinol (DubH2), 5,5'-dithiobis 2-nitrobenzoic acid (DTNB), potassium cyanide $(\mathrm{KCN})$, potassium phosphate buffer (KP), ubiquinone1 (Ub1), antimycin A, cyclosporin A (Cs.A), gallic acid (GA), Malonate, Tween-20, bovine serum albumin (BSA), N-(2-hydroxyethyl) pi-perazine-N '-(2-ethanesulfonic acid) (HEPES), Ethylene glycol-bis( $\beta$-aminoethyl ether (EGTA), Rhodamine123, Trichloroacetic acid (TCA), Coomassie Brilliant Blue, 4,5-dimethylthiazol-2-yl)-2,5-diphenyltetrazolium bromide (MTT), Celecoxib, Dimethyl sulfoxide (DMSO), 2 ',7'-dichlorofuorescin diacetate (DCFH-DA), Thiobarbituric acid (TBA), Butylated Hydroxytoluene (BHT), 2,2',2",2'"-(Ethane-1,2-diyldinitrilo)tetraacetic acid (EDTA), Monopotassium phosphate, 2-Amino-2-hydroxymethyl-propane-1,3-diol (TRIS), Dimethyl sulfoxide (DMSO), 3morpholinopropane-1-sulfonic acid (MOPS),Sucrose, D-mannitol, Rotenone, Sodium succinate, Potassium chloride and Magnesium chloride were purchased from Sigma (St. Louis, MO USA) (Cambridge. UK). Xylazine (CEVA Santé Animale, Naaldwijk, the Netherlands), Ketamine (Ketaset ${ }^{\circledR}$, Eurovet Animal Health, Bladel, the Netherlands).

\section{Mitochondrial Isolation}

Cardiac mitochondria were isolated from male wistar rats. Briefly, animals were deeply anesthetized by a combination of ketamine $(50 \mathrm{mg} / \mathrm{kg})$ and xylazine $(10 \mathrm{mg} / \mathrm{kg})$ via intraperitoneal (i.p.) injection and were euthanized by decapitation, then heart was dissected, chopped, cleared from blood and minced with $10 \mathrm{ml}$ glass homogenizer in the isolation buffer (225 mM D-mannitol, $75 \mathrm{mM}$ sucrose, and $0.2 \mathrm{mM}$ EDTA, $\mathrm{pH}$ 7.4) on ice. The obtained samples were centrifuged at $1000 \mathrm{~g}$ for 10 minutes and the pellet was

removed. The supernatant with mitochondria was poured into ice-cold tube, followed by centrifugation at $10000 \mathrm{~g}$ for 10 minutes (19). The mitochondrial enriched pellets were suspended in appropriate buffer for each test including SDH activity, MMP collapse, ROS formation and lipid peroxidation (LP) assay. The Bradford assay was used for the protein content of mitochondria to standardize (20). Protein concentration of the mitochondria for reach test was adjusted to $1 \mathrm{mg} / \mathrm{mL}$. The integrity and purity of mitochondria were tested by using SDH and lactate dehydrogenase assays.

\section{Mitochondrial Function}

The SDH activity or complex II was measured as mitochondrial function in isolated mitochondria using of MTT reduction at $570 \mathrm{~nm}$ (21). Briefly, after incubation of rat heart isolated mitochondria in assay buffer (3 mM HEPES, $5 \mathrm{mM}$ succinate, $70 \mathrm{mM}$ sucrose, $2 \mathrm{mM}$ Tris-phosphate, $230 \mathrm{mM}$ mannitol and $1 \mu \mathrm{M}$ of rotenone) with celecoxib $(0-100 \mu \mathrm{g} / \mathrm{ml})$ at $37^{\circ} \mathrm{C}$ for $60 \mathrm{~min}$. After 1 hour $0.4 \%$ MTT was added to the medium and incubated at $37^{\circ} \mathrm{C}$ for $30 \mathrm{~min}$. The purple formazan crystals were dissolved in DMSO and the absorbance was measured at $570 \mathrm{~nm}$ with an ELISA reader (BioTek, USA) (22).

\section{Determination of mitochondrial swelling}


Swelling of mitochondria as an indicator of mitochondrial permeability transition pore (mPTP) opening in the presence or absence of celecoxib was determined by monitoring the decrease in light scattering at $540 \mathrm{~nm}$ as described previously (23). Rat heart isolated mitochondria were incubated at $37^{\circ} \mathrm{C}$ in $100 \mu \mathrm{l}$ buffer containing $230 \mathrm{mM}$ mannitol, $70 \mathrm{mM}$ sucrose, $3 \mathrm{mM}$ HEPES, $5 \mathrm{mM}$ succinate, $2 \mathrm{mM}$ Trisphosphate and $1 \mu \mathrm{M}$ of rotenone. The absorbance was monitored at $540 \mathrm{~nm}$ during $60 \mathrm{~min}$ with an ELISA reader (BioTek, USA). A decrease in the absorbance indicates an increase in mitochondrial swelling. Cyclosporine A ( $5 \mu \mathrm{M})$, a PTP inhibitor, was added to verify PTP dependence of mitochondrial swelling. $\mathrm{CaCl}_{2}(100 \mu \mathrm{M})$, as a known inducer of mitochondrial permeability transition (MPT) was used as a positive control.

\section{Measurement of mitochondrial ROS Formation}

After incubation of rat heart isolated mitochondria in the presence or absence of celecoxib in $100 \mu \mathrm{l}$ respiration buffer containing $10 \mathrm{mM}$ Tris, $50 \mu \mathrm{M}$ EGTA, $0.32 \mathrm{mM}$ sucrose, $20 \mathrm{mM}$ Mops, $0.1 \mathrm{mM} \mathrm{KH}_{2} \mathrm{PO}_{4}$, $0.5 \mathrm{mM} \mathrm{MgCl}_{2}, 5 \mathrm{mM}$ sodium succinate and $10 \mu \mathrm{M} \mathrm{DCFH-DA}$ at $37^{\circ} \mathrm{C}$. Gallic acid (50 $\left.\mu \mathrm{M}\right)$, an antioxidant and ROS scavenger, was added to verify celecoxib-induced ROS formation. Hydrogen peroxide $\left(\mathrm{H}_{2} \mathrm{O}_{2}\right)$ was used as a positive control $(100 \mu \mathrm{M})$. The mitochondrial $\mathrm{H}_{2} \mathrm{O}_{2}$ production was measured by flowcytometry (Cyflow Space-Partec, Germany) in the period of $60 \mathrm{~min}$. Mitochondria were read on the FL1 channel of flowcytometry and mean of fluorescence intensities were compared between groups (22).

\section{Determination of MMP collapse}

Using rhodamine 123 staining, MMP collapse was measured. Rhodamine 123 can enter the mitochondrial matrix and the fluorescence strength reflects mitochondrial transmembrane potential. Briefly, rat heart isolated mitochondria were suspended in the presence or absence of celecoxib in $100 \mu \mathrm{l}$ MMP buffer containing $68 \mathrm{mM}$ D-mannitol, $220 \mathrm{mM}$ sucrose, $5 \mathrm{mM} \mathrm{KH}_{2} \mathrm{PO}_{4}, 10 \mathrm{mM} \mathrm{KCl}, 50 \mu \mathrm{M}$ EGTA, $2 \mathrm{mM} \mathrm{MgCl}_{2}, 10 \mathrm{mM}$ HEPES, $2 \mu \mathrm{M}$ rotenone, $5 \mathrm{mM}$ sodium succinate and $10 \mu \mathrm{M}$ of rhodamine 123 at $37^{\circ} \mathrm{C}$ for $60 \mathrm{~min}$. Cyclosporine A $(5 \mu \mathrm{M})$, a PTP inhibitor, was added to verify PTP dependence of MMP collapse. $\mathrm{CaCl}_{2}(100 \mu \mathrm{M})$, as a known inducer of mitochondrial permeability transition (MPT) was used as a positive control. The fluorescence was measured using flowcytometry (Cyflow Space-Partec, Germany). Mitochondria were read on the FL1 channel of flowcytometry and mean of fluorescence intensities were compared between groups (22).

\section{Quantification of Lipid Peroxidation}

Lipid peroxidation was measured by using the thiobarbituric acid assay and MDA formation. The rat heart isolated mitochondria were exposed with and without celecoxib at $37^{\circ} \mathrm{C}$ for $60 \mathrm{~min}$. Then, mitochondria were lysed in a tube containing $1 \mathrm{ml} 0.1 \%(\mathrm{w} / \mathrm{v})$ TCA and centrifugated at $10,000 \mathrm{xg}$ for $10 \mathrm{~min}$. The obtained supernatant was transport to a new tube containing $4 \mathrm{ml}$ of $20 \%$ TCA and $0.5 \%$ TBA. The mixture was boiled at $95^{\circ} \mathrm{C}$ for $15 \mathrm{~min}$ and quickly cooled on ice. The tubes were centrifugated again $10,000 \times \mathrm{g}$ for $5 \mathrm{~min}$ and the optical density of supernatant measured at $532 \mathrm{~nm}$ (24).

\section{Mitochondrial complexes estimation}


In order to maximize the enzymatic rates, isolated mitochondria were subjected to three cycles of freezethawing in hypotonic buffer, before measuring complex I. To complex I activity, $50 \mu \mathrm{g}$ of rat heart isolated mitochondria were added to $700 \mu \mathrm{l}$ of distilled water in 24-well plates. In the following, $60 \mu \mathrm{l}$ of fatty acid-free BSA ( $50 \mathrm{mg} / \mathrm{ml}), 100 \mu \mathrm{l}$ of potassium phosphate buffer $(0.5 \mathrm{M}, \mathrm{pH} 7.5), 30 \mu \mathrm{l}$ of KCN (10 mM) and $10 \mu \mathrm{l}$ of NADH (10 mM) were added. The well was adjusted to the volume $994 \mu \mathrm{l}$ with distilled water. In parallel, a separate cuvette containing the same quantity of reagents and sample but with the addition of $10 \mu \mathrm{l}$ of $1 \mathrm{mM}$ rotenone solution was prepared. After mixing the baseline was read at $340 \mathrm{~nm}$ for $2 \mathrm{~min}$. The reaction was started with adding $6 \mu \mathrm{l}$ of ubiquinone $1(10 \mathrm{mM})$, and followed the decrease of absorbance at $340 \mathrm{~nm}$ for $2 \mathrm{~min}(25)$.

Complex-II (succinate dehydrogenase (SDH) activity)

To assay the complex II activity, $10 \mu \mathrm{g}$ of rat heart isolated mitochondria, $50 \mu \mathrm{l}$ of potassium phosphate buffer $(0.5 \mathrm{M}, \mathrm{pH} 7.5), 600 \mu \mathrm{l}$ of distilled water, $20 \mu \mathrm{l}$ of fatty acid-free BSA $(50 \mathrm{mg} / \mathrm{ml}), 50 \mu \mathrm{l}$ of succinate $(400 \mathrm{mM}), 30 \mu \mathrm{l}$ of KCN $(10 \mathrm{mM})$ and $145 \mu \mathrm{l}$ of DCPIP $(0.015 \%$ (wt/vol)) were added to 24-well plates. In the following, the well was adjusted to the volume $996 \mu$ with distilled water. After mixing, the sample was incubated inside the spectrophotometer at $37^{\circ} \mathrm{C}$ for $10 \mathrm{~min}$ and then read the baseline activity at $600 \mathrm{~nm}$ for the last $2 \mathrm{~min}$. The reaction was start by adding $4 \mu \mathrm{l}$ of $12.5 \mathrm{mM}$ DUB and followed the decrease of absorbance at $600 \mathrm{~nm}$ for $3 \mathrm{~min}$. The specificity of complex II activity was checked by running the assay after the addition of $10 \mu \mathrm{l}$ of $1 \mathrm{M}$ malonate before starting the reaction (25).

Complex III (c III, decylubiquinol cytochrome c oxidoreductase)

To assay the complex III activity, $1 \mu \mathrm{g}$ of rat heart isolated mitochondria, $730 \mu \mathrm{l}$ of distilled water, $75 \mu \mathrm{I}$ of oxidized cytochrome c, $50 \mu$ l of potassium phosphate buffer $(0.5 \mathrm{M}, \mathrm{pH} 7.5), 10 \mu$ I of Tween-20 (2.5\% ( $\mathrm{vol} / \mathrm{vol})) 50 \mu \mathrm{l}$ of KCN $(10 \mathrm{mM})$ and $20 \mu$ I of EDTA $(5 \mathrm{mM}, \mathrm{pH} 7.5)$ were added to 24-well plates. In parallel, a separate well containing the same quantity of reagents and sample with the addition of $10 \mu \mathrm{l}$ of $1 \mathrm{mg} / \mathrm{ml}$ antimycin A solution was prepared. In the following, the wells were adjusted the volume to $990 \mu \mathrm{l}$ with distilled water. After mixing the wells the baseline at $550 \mathrm{~nm}$ for $2 \mathrm{~min}$ was read. The reaction was started by adding $10 \mu \mathrm{l}$ of $10 \mathrm{mM}$ decylubiquinol and mixed rapidly, and immediately observe the increase in absorbance at $550 \mathrm{~nm}$ for 1-2 $\min (25)$.

Complex IV (cytochrome c oxidase)

To assay the complex IV activity, $400 \mu$ of distilled water, $500 \mu$ of potassium phosphate buffer $(100 \mathrm{mM}, \mathrm{pH} 7.0), 60 \mu \mathrm{l}$ of reduced cytochrome c $(1 \mathrm{mM})$ were added to 24 -well plates and read the baseline activity at $550 \mathrm{~nm}$ for the last $2 \mathrm{~min}$. in the following, was adjusted the volume to $995 \mu \mathrm{l}$ with distilled water. The reaction was started by adding $5 \mu \mathrm{l}$ of sample $(2.5 \mu \mathrm{g}$ of rat heart isolated mitochondria proteins) then after the mixing was monitored the decrease of absorbance at $550 \mathrm{~nm}$ for 
$3 \mathrm{~min}$. The specificity of complex IV activity was checked by adding $30 \mu \mathrm{l}$ of $10 \mathrm{mM} \mathrm{KCN}$ in a separate reaction prepared as described above (25).

Complex I + III (NADH cytochrome c oxidoreductase)

To assay the complex, I+ III activity, $6 \mu \mathrm{g}$ of rat heart isolated mitochondria in $700 \mu \mathrm{l}$ of distilled water in a 4-ml well was incubated for 2 min to induce an osmotic shock. In the following, $100 \mu$ l of potassium phosphate buffer $(0.5 \mathrm{M}, \mathrm{pH} 7.5), 20 \mu \mathrm{l}$ of fatty acid-free BSA $(50 \mathrm{mg} / \mathrm{ml}), 30 \mu \mathrm{l}$ of KCN $(10 \mathrm{mM})$ and $50 \mu \mathrm{l}$ of oxidized cytochrome c $(1 \mathrm{mM})$ were added to the 24 well plates. The volume was adjusted to $980 \mu \mathrm{l}$ with distilled water. In parallel, a separate well containing the same quantity of reagents and sample plus $10 \mu \mathrm{l}$ of $1 \mathrm{mM}$ rotenone solution. After mixing the wells, the baseline was read at $550 \mathrm{~nm}$ for $2 \mathrm{~min}$. The reaction was started by adding $20 \mu \mathrm{l}$ of $10 \mathrm{mM} \mathrm{NADH}$, and then followed the increase of absorbance at $550 \mathrm{~nm}$ for $2 \mathrm{~min}$. Specific complex I+ III activity is the rotenone-sensitive activity (25).

Complex II + III (succinate cytochrome c reductase)

To assay the complex II + III activity, at a 24 well plates, was added the sample $(1 \mu \mathrm{g}$ of rat heart isolated mitochondria), $800 \mu$ l of distilled water, $25 \mu$ l of succinate $(400 \mathrm{mM}), 30 \mu \mathrm{l}$ of KCN $(10 \mathrm{mM}), 40 \mu \mathrm{l}$ of potassium phosphate buffer $(0.5 \mathrm{M}, \mathrm{pH} 7.5)$, and then was adjusted the volume to $950 \mu \mathrm{l}$ with distilled water. After mixing, the plate was incubated for $10 \mathrm{~min}$ inside the spectrophotometer at $37^{\circ} \mathrm{C}$. In the following, the reaction was started by adding $50 \mu \mathrm{l}$ of oxidized cytochrome $\mathrm{c}(1 \mathrm{mM})$, after mixing the well, the increase of absorbance at $550 \mathrm{~nm}$ was followed for $3 \mathrm{~min}$. The specificity of this assay was checked by adding $10 \mu \mathrm{l}$ of $1 \mathrm{M}$ malonate or $1 \mathrm{mg} / \mathrm{ml}$ antimycin $\mathrm{A}$ in a separate well prepared as described (25).

\section{Statistical analysis}

Using Graph Pad Prism (version 5, Graph Pad Software Inc., La Jolla, CA, USA), the results were analyzed. Results were analyzed using the one-way ANOVA test, followed by the post-hoc Tukey posttest and twoway ANOVA followed by the posttest Bonferonie in triplicate. Data were presented as mean \pm SD. Statistical significance was set at $p<0.05$. Also, the flow cytometric data was obtained with Cyflow Space-Partec and analyzed by FlowJo.

\section{Results}

\section{Celecoxib decreases mitochondrial function in rat heart isolated mitochondria}

MTT assay was performed for evaluation of SDH activity as an indicator of mitochondrial function. Isolated mitochondria were treated with various concentrations of celecoxib $(0,1,10,20,50,100 \mu \mathrm{g} / \mathrm{ml})$ at 60 minutes. As shown in Fig. 1, the mitochondrial metabolism of MTT to formazan significantly $(\mathrm{P}<$ 
0.001 ) decreased by celecoxib. Celecoxib at concentration $16 \mu \mathrm{g} / \mathrm{ml}$ decreased $\% 50$ the mitochondrial function in isolated mitochondria (Fig. 1).

\section{Celecoxib increases mitochondrial ROS in rat heart isolated mitochondria}

As shown in Fig. 2, the mean fluorescence intensities of DCF as an indicator of the ROS $\left(\mathrm{H}_{2} \mathrm{O}_{2}\right)$ formation in isolated mitochondria at 60 minutes significantly $(P<0.001)$ increased in presence celecoxib $(16 \mu \mathrm{g} / \mathrm{ml})$. While in the isolated mitochondria cotreated with celecoxib $+\mathrm{GA}$, the mean fluorescence intensities of DCF significantly decreased compared to celecoxib group.

\section{Celecoxib induces mitochondrial swelling in rat heart isolated mitochondria}

Mitochondrial swelling and mitochondrial membrane permeability was monitored at $540 \mathrm{~nm}$. Decrease in absorbance at $540 \mathrm{~nm}$ is indicator of mitochondrial swelling. As shown in Fig. 3, celecoxib $(16 \mu \mathrm{g} / \mathrm{ml})$ significantly $(P<0.001)$ decreased the absorbance at $540 \mathrm{~nm}$. Decrease absorbance at $540 \mathrm{~nm}$ as an indicator of mitochondrial swelling was significantly $(P<0.001)$ inhibited after exposure of isolated mitochondria with combination of Cs. A + celecoxib.

\section{Celecoxib induces MMP collapse in rat heart isolated mitochondria}

The mean fluorescence intensity of the rhodamine 123 as an indicator of MMP collapse was monitored after 60 minutes of exposure. As shown in Fig. 4, celecoxib $(16 \mu \mathrm{g} / \mathrm{ml})$ significantly $(P<0.001)$ induced the MMP collapse in isolated mitochondria during 1-hour of exposure. Collapse of MMP was inhibited after treatment of rat heart isolated mitochondria with combination of Cs.A and celecoxib.

\section{Celecoxib causes lipid peroxidation MMP collapse in rat heart isolated mitochondria}

MDA as by-product of lipid peroxidation in the sample reacts with TBA to generate an MDA-TBA adduct. The MDA-TBA adduct can be easily quantified calorimetrically at $532 \mathrm{~nm}$ as an indicator of lipid peroxidation. There was a significant elevation in MDA $(P<0.001)$ in celecoxib group in comparison with untreated control (Fig. 5).

\section{Celecoxib decrease complex I V activity in rat heart isolated mitochondria}

\section{Mitochondrial complexes estimation}


Conditions for spectrophotometric assays of respiratory chain enzymes activities and mitochondrial complexes enzymatic activity in the presence or absence of celecoxib in rat heart isolated mitochondria were presented in Table 1. Complex I V activity was significantly reduced by celecoxib to $47.48 \%$ of control activity. Activities of complex I, complex II, complex III, complex I + II and complex II + III were not affected by celecoxib. In summary, these results confirm that complex IV is the principal oxidative phosphorylation (OXPHOS) target for celecoxib in rat heart isolated mitochondria. 
Table 1

Conditions for spectrophotometric assays of respiratory chain enzymes activities in the rat heart isolated mitochondria.

\begin{tabular}{|c|c|c|c|c|c|c|}
\hline & Complex I & $\begin{array}{l}\text { Complex } \\
\text { II }\end{array}$ & $\begin{array}{l}\text { Complex } \\
\text { III }\end{array}$ & $\begin{array}{l}\text { Complex } \\
\text { IV }\end{array}$ & $\begin{array}{l}\text { Complex } \\
|+||| l\end{array}$ & $\begin{array}{l}\text { Complex } \\
\text { II + III }\end{array}$ \\
\hline \multicolumn{7}{|l|}{ Conditions } \\
\hline$\lambda(\mathrm{nm})$ & 340 & 600 & 550 & 550 & 550 & 550 \\
\hline Buffer & $\mathrm{KP}$ & $\mathrm{KP}$ & $\mathrm{KP}$ & $\mathrm{KP}$ & $\mathrm{KP}$ & $\mathrm{KP}$ \\
\hline $\mathrm{pH}$ & 7.5 & 7.5 & 7.5 & 7 & 7.5 & 7.5 \\
\hline $\begin{array}{l}\text { Substrates/ } \\
\text { electron } \\
\text { acceptors }\end{array}$ & $\begin{array}{l}\mathrm{NADH} \\
100 \mu \mathrm{M} \\
\text { Ub } \\
1,60 \mu \mathrm{M}\end{array}$ & $\begin{array}{l}\text { Succinate, } \\
20 \mathrm{mM} \\
\text { DCPIP, } \\
80 \mu \mathrm{M} \\
\text { DUB, } \\
50 \mu \mathrm{M}\end{array}$ & $\begin{array}{l}\text { DubH } \\
2,100 \mu \mathrm{M} \\
\text { Cyt c, } \\
75 \mu \mathrm{M}\end{array}$ & $\begin{array}{l}\text { Cyt c H2, } \\
60 \mu \mathrm{M}\end{array}$ & $\begin{array}{l}\mathrm{NADH}, \\
200 \mu \mathrm{M} \\
\text { Cyt c, } \\
50 \mu \mathrm{M}\end{array}$ & $\begin{array}{l}\text { Succinate, } \\
10 \mathrm{mM} \\
\text { Cyt c, } \\
50 \mu \mathrm{M}\end{array}$ \\
\hline Detergent & - & - & $\begin{array}{l}\text { Tween-20 } \\
(0.025 \% \\
\text { (vol/vol) }\end{array}$ & - & - & - \\
\hline $\begin{array}{l}\text { Specific } \\
\text { Inhibitor }\end{array}$ & $\begin{array}{l}\text { Rotenone } \\
10 \mu \mathrm{M}\end{array}$ & $\begin{array}{l}\text { Malonate, } \\
10 \mathrm{mM}\end{array}$ & $\begin{array}{l}\text { Antimycin } \\
\text { A, } \\
10 \mu \mathrm{g} \mathrm{ml}^{-} \\
{ }_{1}\end{array}$ & $\begin{array}{l}\mathrm{KCN}, \\
300 \mu \mathrm{M}\end{array}$ & $\begin{array}{l}\text { Rotenone, } \\
10 \mu \mathrm{M}\end{array}$ & $\begin{array}{l}\text { Malonate, } \\
10 \mathrm{mM}\end{array}$ \\
\hline \multicolumn{7}{|l|}{ Results } \\
\hline $\begin{array}{l}\text { Absorbance in } \\
\text { control group }\end{array}$ & $\begin{array}{l}0.344 \\
\pm .03\end{array}$ & $\begin{array}{l}0.601 \\
\pm .04\end{array}$ & $\begin{array}{l}0.042 \\
\pm .004\end{array}$ & $\begin{array}{l}0.676 \\
\pm .07\end{array}$ & $\begin{array}{l}0.043 \\
\pm .003\end{array}$ & $\begin{array}{l}0.042 \\
\pm .001\end{array}$ \\
\hline $\begin{array}{l}\text { Absorbance in } \\
\text { celecoxib group }\end{array}$ & $\begin{array}{l}0.304 \\
\pm .04\end{array}$ & $\begin{array}{l}0.640 \\
\pm .03\end{array}$ & $\begin{array}{l}0.039 \\
\pm .001\end{array}$ & $\begin{array}{l}0.321 \\
\pm .04^{\mathrm{a}}\end{array}$ & $\begin{array}{l}0.04 \\
\pm .001\end{array}$ & $\begin{array}{l}0.039 \\
\pm .002\end{array}$ \\
\hline $\begin{array}{l}\text { Absorbance in } \\
\text { positive control }\end{array}$ & $\begin{array}{l}0.201 \\
\pm .02^{\mathrm{a}}\end{array}$ & $\begin{array}{l}0.504 \\
\pm .01^{\mathrm{a}}\end{array}$ & $\begin{array}{l}0.027 \\
\pm .002^{\mathrm{a}}\end{array}$ & $\begin{array}{l}0.224 \\
\pm .04^{\mathrm{a}}\end{array}$ & $\begin{array}{l}0.02 \\
\pm .001^{\mathrm{a}}\end{array}$ & $\begin{array}{l}0.019 \\
\pm .002^{\mathrm{a}}\end{array}$ \\
\hline \multicolumn{7}{|c|}{$\begin{array}{l}\text { Abbreviations: } \lambda \text {, selected wavelength for the assay; Cyt c, cytochrome c; } \mathrm{Cyt} \text { c } \mathrm{H} 2 \text {, reduced } \\
\text { cytochrome c; DCPIP, 2,6-dichlorophenolindophenol; DUB, decylubiquinone; DubH2, decylubiquinol; } \\
\text { DTNB, 5,5'-dithiobis ( } 2 \text {-nitrobenzoic acid); KCN, potassium cyanide; KP, potassium phosphate buffer; } \\
\text { Ub1, ubiquinone1. Control group was exposure to celecoxib solvent (DMSO 0.01). Celecoxib group } \\
\text { was exposure to } 16 \mu \mathrm{g} / \mathrm{ml} \text {. Data are expressed as mean } \pm \text { SEM., } \mathrm{n}=3 \text {, a shows significant difference } \\
\text { (p<0.001) with control group. }\end{array}$} \\
\hline
\end{tabular}

\section{Discussion}


Cardiovascular disorder is one of the outstanding causes of death in the worldwide (26). There are many documents that demonstrated a strong relationship between the mitochondrial dysfunctions and cardiac diseases (27). However, understanding of cellular and molecular mechanisms of mitochondrial dysfunctions in creating cardiac disorders and the development of safe prescription drugs without the cardiac toxicity is still considered a challenge (16). Notwithstanding toxic side effects, celecoxib, as a selective COX-2 inhibitor, is usually prescribed, because the its benefits in the different cases (28). Based on such controversy and given the role of mitochondria in causing cardiac toxicity, in the current study, we analyzed the effect of celecoxib on the rat heart isolated mitochondria.

In a dose-dependent use of celecoxib, mitochondrial function decreases considerably. In our experiments, the rat heart isolated mitochondria treated with $1-100 \mu \mathrm{g} / \mathrm{ml}$ of celecoxib for 1 hour showed a similar pattern in cellar study by other (29). This experiment showed that $16 \mu \mathrm{g} / \mathrm{ml}$ of celecoxib decreases $\% 50$ the mitochondrial function in rat heart isolated mitochondria. This preliminary result showed that concentrations of $1 \mu \mathrm{g} / \mathrm{ml}$ of celecoxib is relevant to clinical exposure $(1.28 \mu \mathrm{g} / \mathrm{ml})(30)$, although higher concentrations of the drug, such as $10-100 \mu \mathrm{g} / \mathrm{ml}$ are largely used in cell culture models $(29,31)$. The $16 \mu \mathrm{g} / \mathrm{ml}$ concentration as IC50 was kept to search celecoxib effect in the rat heart isolated mitochondria, as in patients under high doses of celecoxib administration (32).

ROS have a main role in controlling the cell growth and death of cardiac cells. Mitochondria are major targets for ROS damage and also, they are major source of ROS in the cardiomyocytes. In clinical studies and numerous experimental have been reported that accumulation of ROS lead to the failing myocardium. In cardiac pathological conditions such as cardiac ischemia-reperfusion injury (IRI), cardiac hypertrophy, heart failure (HF), and diabetic cardiomyopathy, dysregulated ROS formation and oxidative stress have been indicated. The main source of ROS formation in the heart is related to uncoupling of mitochondrial electron transport chain at the level of complexes. Our results on the rat heart isolated mitochondria indicated that celecoxib could cause ROS formation and oxidative stress. The functions of mitochondrial respiratory chain and other proteins in the mitochondria are sensitive to oxidative changes and ROS formation particularly as a major phospholipid in the inner mitochondrial membrane which is called cardiolipin (33). Cardiolipin is responsible for maintaining the functional integrity of the respiratory chain complexes and other proteins in the mitochondria. Also, overexpression of ROS in the cardiomyocytes can result in mitochondrial dysfunction, mitochondrial swelling, oxidative damage to lipids, proteins and DNA and finally activation of the mitochondrial-permeability transition pore (MPTP) and cell death. Obtained results in this study confirmed that exposure with celecoxib leads to mitochondrial swelling, lipid peroxidation and MMP collapse in rat heart isolated mitochondria.

The greater part of ROS in the cell are generated as a by-product of mitochondrial respiration. The main sites of superoxide formation in mitochondria are complex I and complex III (34). However, in addition to above complexes, complex IV has also an important role in ROS generation (35). It is known that changes in complex IV activity lead to alteration of the electron transport chain with an increase in the generation of ROS (36). Furthermore, alterations in the mitochondrial membrane could be related to an increase of the oxidative stress and cell death (37). The role of complex IV to the activities of complexes I and III 
following their assembly into supercomplexes has been demonstrated (38). Also, there are other potential sources of ROS that are located within the mitochondria including monoamine oxidases (MAO-A and -B), NADPH oxidase 4 and p66Shc (39). Unlike COX-1, COX-2 is not limited to endoplasmic reticulum (ER) and is reported to be located in nucleus and other organelles (40). COX-2 in primary cultured human cells has been reported to localize to endoplasmic reticulum, nuclear envelope, nucleus and other organelles such as mitochondria. Our data indicate that celecoxib inhibits mitochondrial complex IV and probably triggers mitochondrial damage and oxidative stress in isolated mitochondria. It has been reported that druginduced cardiotoxicity is closely associated to mitochondrial damage and oxidative stress (41).

\section{Conclusion}

In conclusion, the presented data in the current study showed that celecoxib induces mitochondrial dysfunction in rat heart mitochondria owing to, its ability to induce ROS production and complex IV inhibition which lead to permeabilizing the mitochondrial membrane and mitochondrial swelling.

\section{Abbreviations}

NSAIDs: Nonsteroidal Anti-Inflammatory Drugs; COX: Cyclooxygenase; PGs: Prostaglandins; TXs: Thromboxanes; PGI2: Prostacyclin; TXA2: thromboxane A2; SDH: Succinate Dehydrogenases; OXPHOS: Oxidative Phosphorylation; ROS: Reactive Oxygen Species; DCFH-DA: Dichlorofluorescein Diacetate; DCF: Dichlorofluorescein; MDA: Malondialdehyde; MMP: Mitochondrial Membrane Potential; MPTP: Mitochondrial-Permeability Transition Pore; IRI: Ischemia-Reperfusion Injury; HF: Heart Failure

\section{Declarations}

\section{Ethics approval and consent to participate}

All protocols were approved by the Ethics Committee at the Ardabil University of Medical Sciences.

\section{Funding}

This study was supported by Ardabil of Medical Sciences, Deputy of Research with grant number IR.ARUMS.REC.1398 for the financial support and providing the materials.

\section{Availability of data and materials}

All data and materials related to the study can be obtained in the Materials and Methods Section.

\section{Authors' contributions}

SA, EMK and SK participated in collected data; PK participated in data support; AS participated in drafting and revising the manuscript and analyzed the data. All authors read and approved the final manuscript. 


\section{Consent for publication}

Not applicable.

\section{Competing interests}

All authors report no competing interests relevant to this study. We declare that Dr. Ahmad Salimi is a member of your Editorial board.

\section{Acknowledgments}

The authors acknowledged all the members for giving their time to participate in the study.

\section{References}

1. Ho KY, Gwee KA, Cheng YK, Yoon KH, Hee HT, Omar AR. Nonsteroidal anti-inflammatory drugs in chronic pain: implications of new data for clinical practice. Journal of pain research. 2018;11:1937.

2. Sostres C, Gargallo CJ, Arroyo MT, Lanas A. Adverse effects of non-steroidal anti-inflammatory drugs (NSAIDs, aspirin and coxibs) on upper gastrointestinal tract. Best practice \& research Clinical gastroenterology. 2010;24(2):121-32.

3. Meek IL, Van de Laar MA, E Vonkeman H. Non-steroidal anti-inflammatory drugs: an overview of cardiovascular risks. Pharmaceuticals. 2010;3(7):2146-62.

4. Nørregaard R, Kwon T-H, Frøkiær J. Physiology and pathophysiology of cyclooxygenase-2 and prostaglandin E2 in the kidney. Kidney research and clinical practice. 2015;34(4):194-200.

5. Zarghi A, Arfaei S. Selective COX-2 inhibitors: a review of their structure-activity relationships. Iranian journal of pharmaceutical research: IJPR. 2011;10(4):655.

6. Cannon CP, Cannon PJ. COX-2 inhibitors and cardiovascular risk. Science. 2012;336(6087):1386-7.

7. Nissen SE, Yeomans ND, Solomon DH, Lüscher TF, Libby P, Husni ME, et al. Cardiovascular safety of celecoxib, naproxen, or ibuprofen for arthritis. New England Journal of Medicine. 2016;375:2519-29.

8. Caldwell B, Aldington S, Weatherall M, Shirtcliffe P, Beasley R. Risk of cardiovascular events and celecoxib: a systematic review and meta-analysis. Journal of the Royal Society of Medicine. 2006;99(3):132-40.

9. Ahmad S, Panda BP, Fahim M, Dhyani N, Dubey K. Ameliorative effect of beraprost sodium on celecoxib induced cardiotoxicity in rats. Iranian journal of pharmaceutical research: IJPR. 2018;17(1):155.

10. Ahmad S, Panda BP, Kohli K, Fahim M, Dubey K. Folic acid ameliorates celecoxib cardiotoxicity in a doxorubicin heart failure rat model. Pharmaceutical biology. 2017;55(1):1295-303.

11. Olszewska A, Szewczyk A. Mitochondria as a pharmacological target: magnum overview. IUBMB life. 2013;65(3):273-81. 
12. Salimi A, Neshat MR, Naserzadeh P, Pourahmad J. Mitochondrial permeability transition pore sealing agents and antioxidants protect oxidative stress and mitochondrial dysfunction induced by naproxen, diclofenac and celecoxib. Drug research. 2019;69(11):598-605.

13. Ghosh R, Alajbegovic A, Gomes AV. NSAIDs and cardiovascular diseases: role of reactive oxygen species. Oxidative medicine and cellular longevity. 2015;2015.

14. Meyer JN, Hartman JH, Mello DF. Mitochondrial toxicity. Toxicological Sciences. 2018;162(1):15-23.

15. Varga ZV, Pacher P. Cardiotoxicity of Drugs: Role of Mitochondria. Mitochondrial Dysfunction Caused by Drugs and Environmental Toxicants. 2018:93-110.

16. Varga ZV, Ferdinandy P, Liaudet L, Pacher P. Drug-induced mitochondrial dysfunction and cardiotoxicity. American Journal of Physiology-Heart and Circulatory Physiology. 2015;309(9):H1453-H67.

17. Rana P, Aleo MD, Gosink M, Will Y. Evaluation of in vitro mitochondrial toxicity assays and physicochemical properties for prediction of organ toxicity using 228 pharmaceutical drugs. Chemical research in toxicology. 2018;32(1):156-67.

18. Kelleni MT, Abdelbasset M. Drug Induced Cardiotoxicity: Mechanism, Prevention and Management. Cardiotoxicity. 2018:127.

19. Huang L, Zhang K, Guo Y, Huang F, Yang K, Chen L, et al. Honokiol protects against doxorubicin cardiotoxicity via improving mitochondrial function in mouse hearts. Scientific reports. 2017;7(1):112.

20. Bradford MM. A rapid and sensitive method for the quantitation of microgram quantities of protein utilizing the principle of protein-dye binding. Analytical biochemistry. 1976;72(1):248-54.

21. Hosseini M-J, Naserzadeh P, Salimi A, Pourahmad J. Toxicity of cigarette smoke on isolated lung, heart, and brain mitochondria: induction of oxidative stress and cytochrome c release. Toxicological \& Environmental Chemistry. 2013;95(9):1624-37.

22. Salimi A, Roudkenar MH, Seydi E, Sadeghi L, Mohseni A, Pirahmadi N, et al. Chrysin as an anti-cancer agent exerts selective toxicity by directly inhibiting mitochondrial complex II and V in CLL Blymphocytes. Cancer investigation. 2017;35(3):174-86.

23. Escobales N, Nuñez RE, Jang S, Parodi-Rullan R, Ayala-Peña S, Sacher JR, et al. Mitochondriatargeted ROS scavenger improves post-ischemic recovery of cardiac function and attenuates mitochondrial abnormalities in aged rats. Journal of molecular and cellular cardiology. 2014;77:13646.

24. Beach DC, Giroux E. Inhibition of lipid peroxidation promoted by iron (III) and ascorbate. Archives of biochemistry and biophysics. 1992;297(2):258-64.

25. Spinazzi M, Casarin A, Pertegato V, Salviati L, Angelini C. Assessment of mitochondrial respiratory chain enzymatic activities on tissues and cultured cells. Nature protocols. 2012;7(6):1235.

26. Mc Namara K, Alzubaidi H, Jackson JK. Cardiovascular disease as a leading cause of death: how are pharmacists getting involved? Integrated pharmacy research \& practice. 2019;8:1. 
27. Knowlton AA, Le Chen ZAM. Heart failure and mitochondrial dysfunction: the role of mitochondrial fission/fusion abnormalities and new therapeutic strategies. Journal of cardiovascular pharmacology. 2014;63(3):196.

28. Mendes RT, Stanczyk CP, Sordi R, Otuki MF, dos Santos FA, Fernandes D. Selective inhibition of cyclooxygenase-2: risks and benefits. Rev Bras Reumatol. 2012;52(5):767-82.

29. Sakane K, Monteiro C, Silva W, Silva A, Santos P, Lima K, et al. Cellular and molecular studies of the effects of a selective COX-2 inhibitor celecoxib in the cardiac cell line $\mathrm{H} 9 \mathrm{c} 2$ and their correlation with death mechanisms. Brazilian Journal of Medical and Biological Research. 2014;47(1):50-9.

30. Birmingham B, Buvanendran A. Nonsteroidal anti-inflammatory drugs, acetaminophen, and COX-2 inhibitors. Practical Management of Pain: Elsevier; 2014. p. 553-68. e5.

31. Hasinoff BB, Patel D, Wu X. The cytotoxicity of celecoxib towards cardiac myocytes is cyclooxygenase-2 independent. Cardiovascular toxicology. 2007;7(1):19-27.

32. Qin W, Zhu W, Hewett JE, Rottinghaus G, Chen Y-C, Flynn JT, et al. UPA is upregulated by high dose celecoxib in women at increased risk of developing breast cancer. BMC cancer. 2008;8(1):298.

33. Osman C, Voelker DR, Langer T. Making heads or tails of phospholipids in mitochondria. Journal of Cell Biology. 2011;192(1):7-16.

34. Lambert AJ, Brand MD. Reactive oxygen species production by mitochondria. Mitochondrial DNA: Springer; 2009. p. 165-81.

35. Mansilla N, Racca S, Gras DE, Gonzalez DH, Welchen E. The complexity of mitochondrial complex IV: an update of cytochrome c oxidase biogenesis in plants. International journal of molecular sciences. 2018;19(3):662.

36. Zhao RZ, Jiang S, Zhang L, Yu ZB. Mitochondrial electron transport chain, ROS generation and uncoupling. International journal of molecular medicine. 2019;44(1):3-15.

37. Ott M, Gogvadze V, Orrenius S, Zhivotovsky B. Mitochondria, oxidative stress and cell death. Apoptosis. 2007;12(5):913-22.

38. Schäfer E, Seelert H, Reifschneider NH, Krause F, Dencher NA, Vonck J. Architecture of active mammalian respiratory chain supercomplexes. Journal of Biological Chemistry. 2006;281(22):15370-5.

39. Di Lisa F, Kaludercic N, Carpi A, Menabò R, Giorgio M. Mitochondrial pathways for ROS formation and myocardial injury: the relevance of p66 Shc and monoamine oxidase. Basic research in cardiology. 2009;104(2):131-9.

40. Liou J-Y, Shyue S-K, Tsai M-J, Chung C-L, Chu K-Y, Wu KK. Colocalization of prostacyclin synthase with prostaglandin $\mathrm{H}$ synthase-1 (PGHS-1) but not phorbol ester-induced PGHS-2 in cultured endothelial cells. Journal of Biological Chemistry. 2000;275(20):15314-20.

41. Deavall DG, Martin EA, Horner JM, Roberts R. Drug-induced oxidative stress and toxicity. Journal of toxicology. 2012;2012. 
Figures

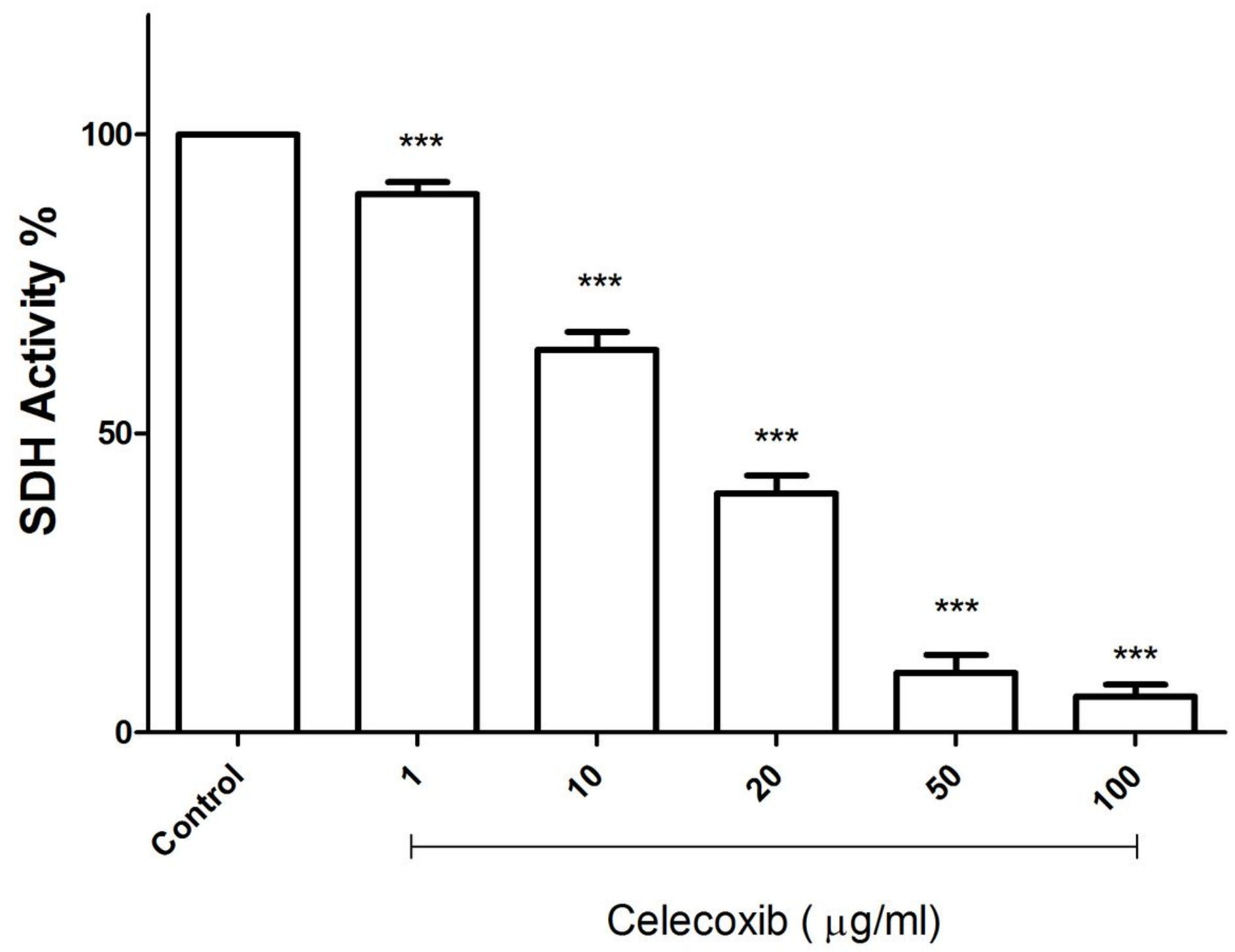

Figure 1

Effect of celecoxib on succinate dehydrogenase activity in isolated rat heart mitochondria. Mitochondrial succinate dehydrogenase activity was measured by MTT assay within $1 \mathrm{~h}$. Presented data showed celecoxib significantly decreased succinate dehydrogenase activity compared to control. $16 \mu \mathrm{g} / \mathrm{ml}$ of celecoxib decreases $\% 50$ the mitochondrial function in rat heart isolated mitochondria. Values were expressed as mean \pm SD of three separate determinations. ${ }^{\star \star \star}$ indicates $p<0.001 \mathrm{vs.} \mathrm{control.}$ 


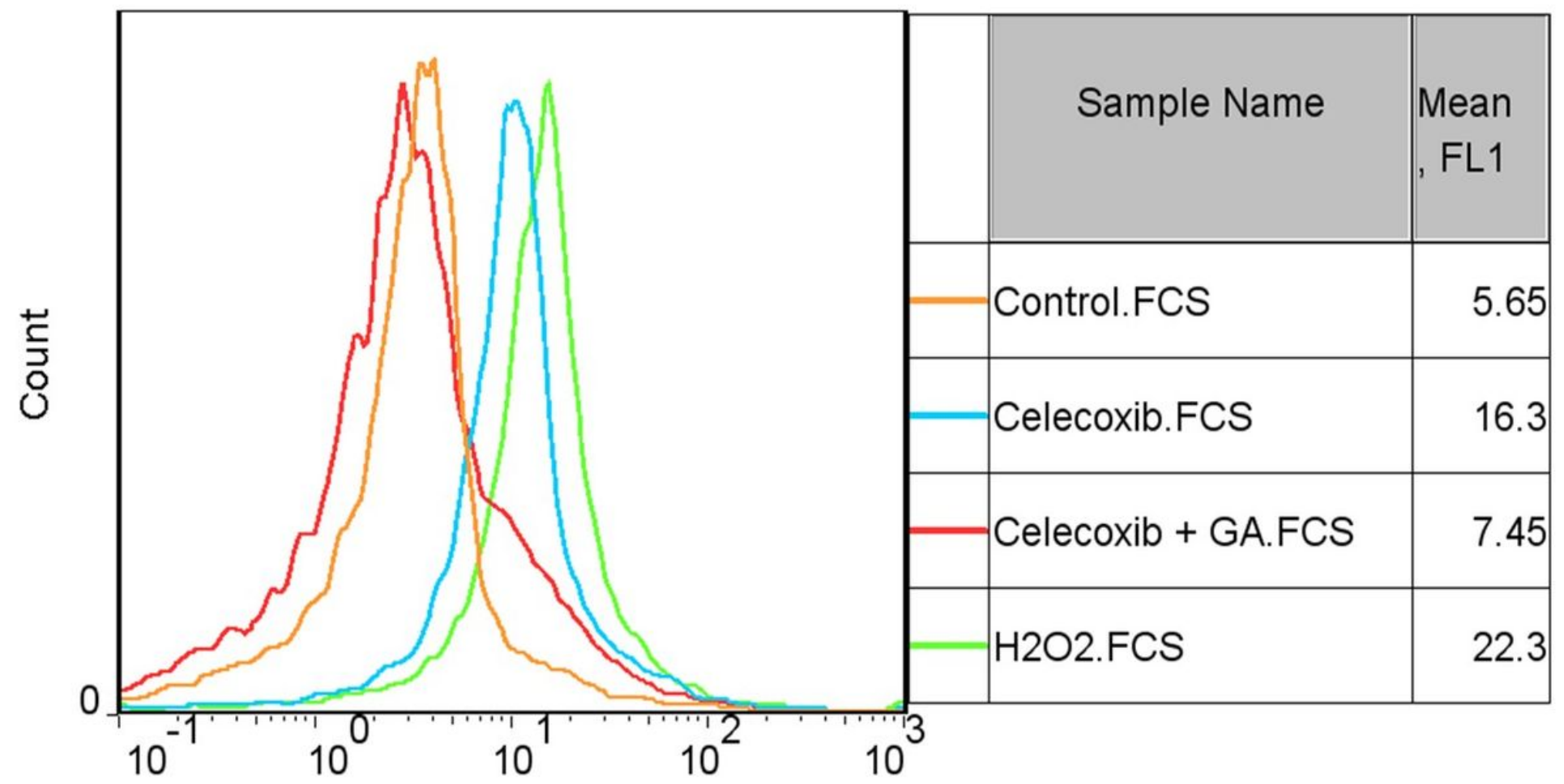

FL1:: DCF-DA

Figure 2

Effect of celecoxib on ROS formation in isolated rat heart mitochondria. Changes in ROS generation were measured in isolated mitochondria after treatment with celecoxib $(16 \mu \mathrm{g} / \mathrm{ml})$ for $1 \mathrm{~h}$. The fluorescence intensity of DCF was significantly increased in celecoxib-treated mitochondria. 


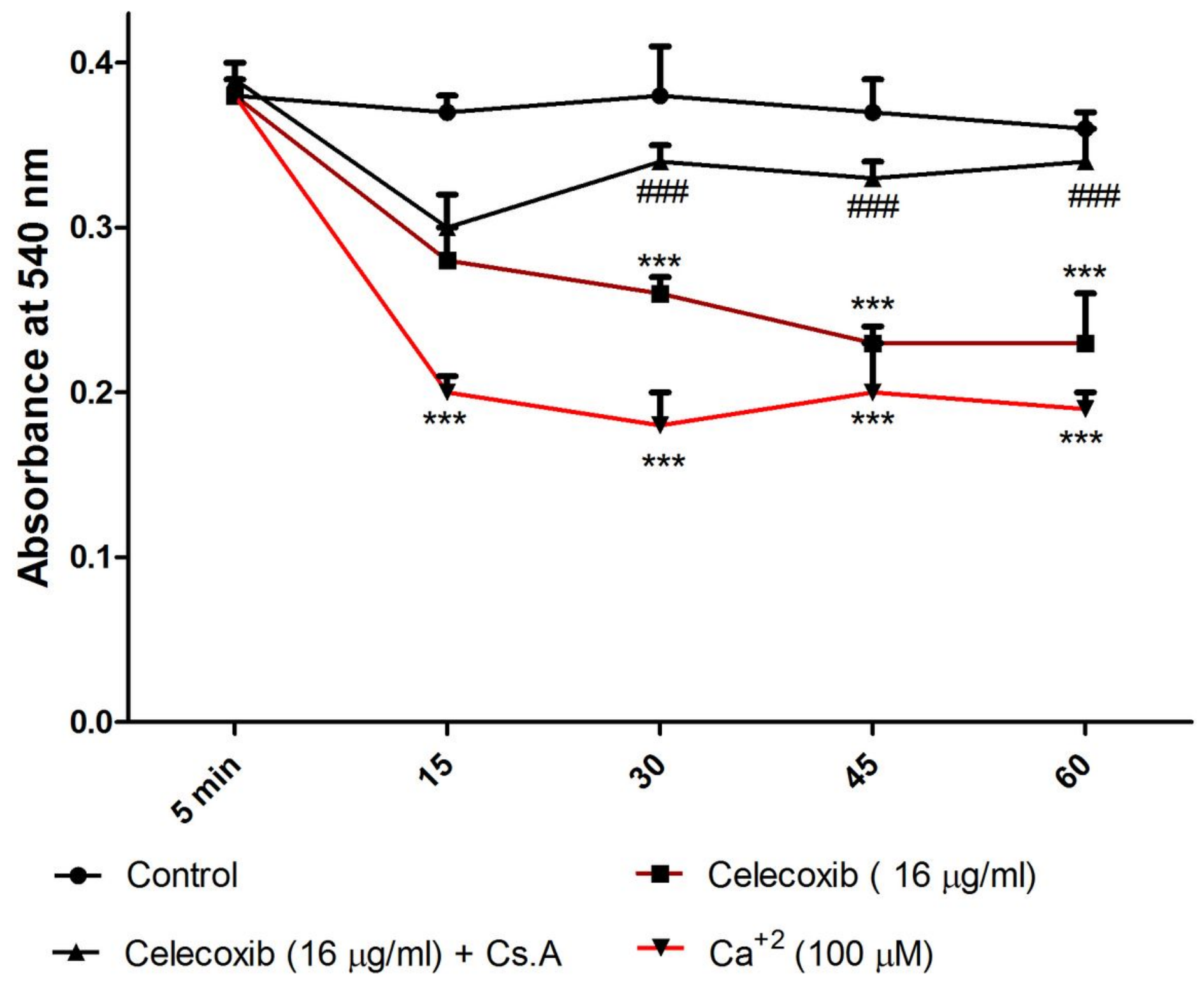

Figure 3

Effect of celecoxib on mitochondrial swelling in isolated rat heart mitochondria. Mitochondrial swelling was monitored by following $540 \mathrm{~nm}$ absorbance decrease. Celecoxib at concentration $5016 \mu \mathrm{g} / \mathrm{ml}$ induced mitochondrial swelling in in isolated rat heart mitochondria in a time depending manner. Values were expressed as mean \pm SD of three separate determinations. ${ }^{\star * \star}$ indicates $p<0.001$ vs. control. 


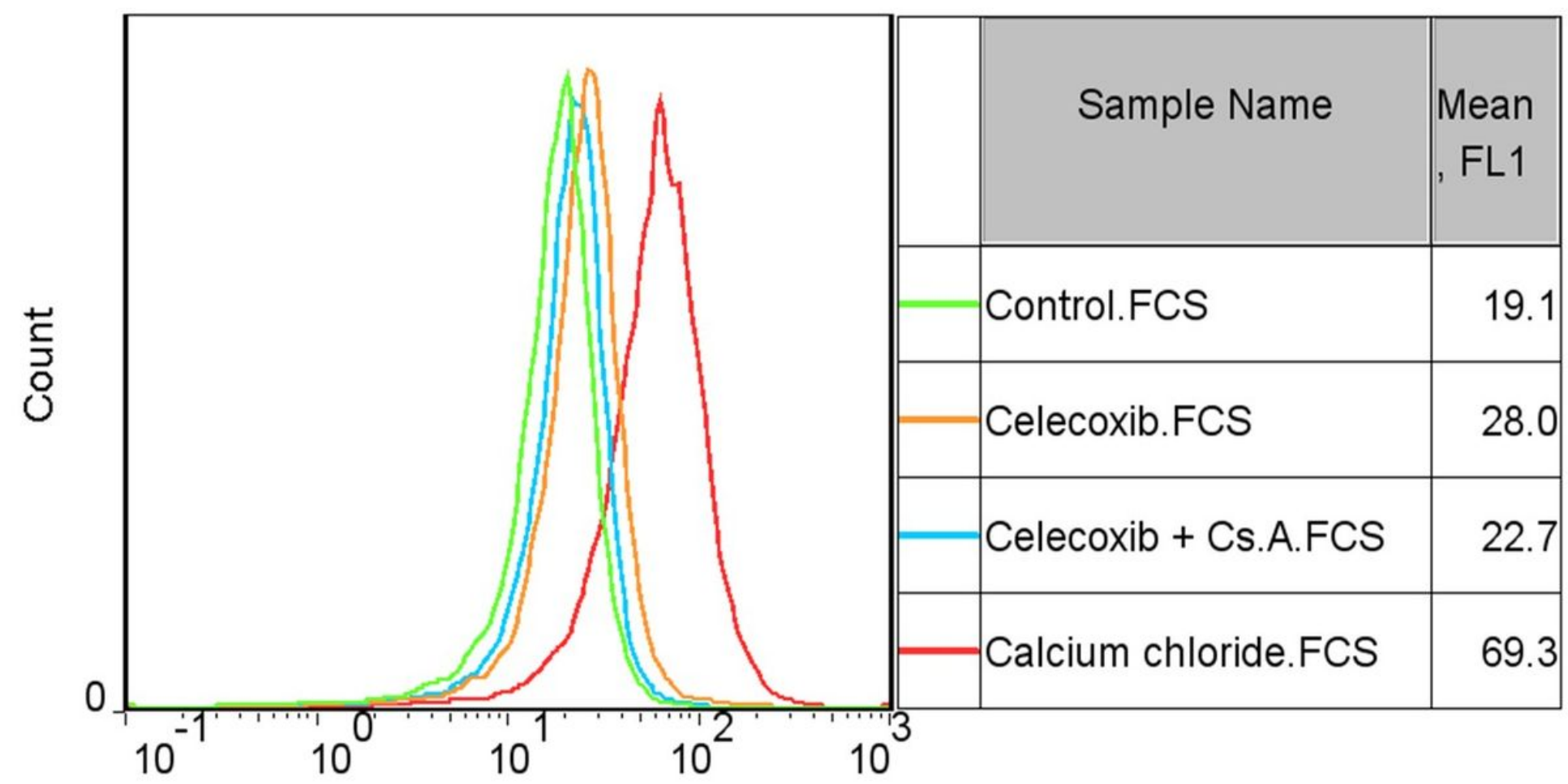

FL1:: Rhodamine 123

\section{Figure 4}

Effect of celecoxib on $\Delta \Psi_{\mathrm{m}}$ in isolated rat heart mitochondria. Freshly isolated mitochondria were incubated with $16 \mu \mathrm{g} / \mathrm{ml}$ celecoxib for $1 \mathrm{~h} . \Delta \Psi \mathrm{m}$ was measured following rhodamine 123 staining with flow cytometry. The presented data revealed that exposure to celecoxib caused a significant increase in the fluorescence intensity of rhodamine 123 and it reflects MMP collapse. 


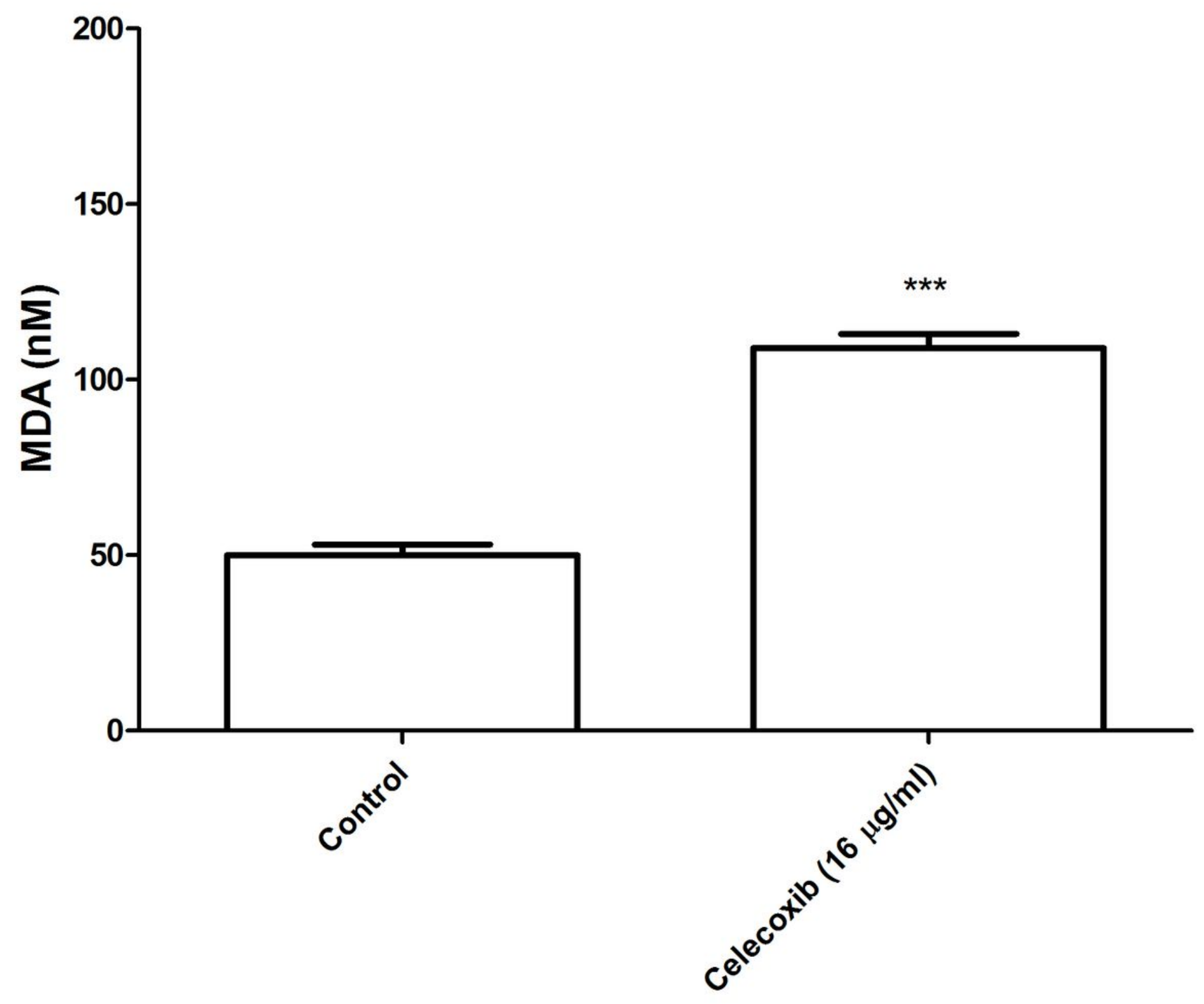

Figure 5

Effect of celecoxib on lipid peroxidation in isolated rat heart mitochondria. Induction of lipid peroxidation in isolated mitochondria and after incubation with celecoxib. Lipid peroxidation significantly increased when isolated mitochondria were incubated with celecoxib (A). Values were expressed as mean \pm SD of three separate determinations. $* \star \star$ indicates $\mathrm{p}<0.001 \mathrm{vs}$. control.

\section{Supplementary Files}

This is a list of supplementary files associated with this preprint. Click to download. 
- NC3RsARRIVEGuidelinesChecklist.doc 